\title{
Cadmium and Chromium Toxicity to Pseudokirchneriella subcapitata and Microcystis aeruginosa
}

\author{
Suzelei Rodgher ${ }^{1 *}$, Evaldo Luiz Gaeta Espíndola ${ }^{1}$, Fernanda Cristina Fonseca Simões ${ }^{1}$ and \\ Alessandra Emanuele Tonietto ${ }^{2}$ \\ ${ }^{1}$ Centro de Recursos Hídricos e Ecologia Aplicada; Escola de Engenharia de São Carlos; Universidade de São \\ Paulo; Av. Trabalhador São Carlense, 400; C. P.: 292; 13560-97; São Carlos - SP - Brasil. ${ }^{2}$ Departamento de \\ Química; Universidade Federal de São Carlos; Via Washington Luiz, km 235; C. P.: 676.; 13565-970; São Carlos - \\ SP - Brasil
}

\begin{abstract}
The toxicity of cadmium and chromium to Pseudokirchneriella subcapitata and Microcystis aeruginosa was evaluated through algal growth rate during $96 \mathrm{~h}$ exposure bioassays. Free metal ion concentrations were obtained using MINEQL ${ }^{+} 4.61$ and used for IC50 determination. Metal accumulations by the microorganisms were determined and they were found to be dependent on the concentration of $\mathrm{Cd}^{2+}$ and $\mathrm{Cr}^{6+}$. IC50 for P. subcapitata were $0.60 \mu \mathrm{mol} \mathrm{L} \mathrm{L}^{-1}$ free $\mathrm{Cd}^{2+}$ and $20 \mu \mathrm{mol} \mathrm{L}{ }^{-1}$ free $\mathrm{Cr}^{6+}$, while the IC50

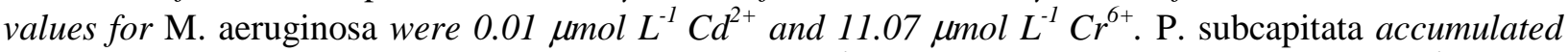

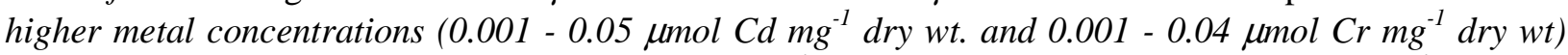
than the cyanobacteria (0.001 - $0.01 \mu \mathrm{mol} C d \mathrm{mg}^{-1} \mathrm{dry} w \mathrm{w}$ and $0.001-0.02 \mu \mathrm{mol} \mathrm{Cr} \mathrm{mg}^{-1} \mathrm{dry} w \mathrm{w}$ ). Cadmium was more toxic than chromium to both the microorganisms.
\end{abstract}

Key words: Toxic effects, algae sensitivity, metal accumulation, IC50

\section{INTRODUCTION}

The release of different pollutants into the environment has increased as result of industrialization, and thereby, lowered the environment quality to alarming levels. Among such pollutants, trace metals are most important because they interact with the biota and may be highly toxic; they accumulate in the environment and represent a potential health hazard for humans. Metals may associate with some ecosystem components resulting in metal complexes with inorganic or organic materials. Considering the amplitude of possibilities for the metal association in the environment, metals bioavailability may vary with environmental conditions and organisms (Lombardi et al. 2002; De Schamphelaere et al. 2005; Töpperwien et al. 2007).

Metals such as cadmium and chromium are often present in industrial wastewaters. Cadmium originates from metal plating, metallurgical alloying, mining, ceramics and other industrial operations (Davis et al. 2000), and chromium from tanning factories, steel works, industrial electroplating, wood preservation and artificial fertilizers (Bagchi et al. 2002).

The toxic effect of heavy metals on aquatic biota is one of the main problems arising from the contamination of natural aquatic ecosystems. Algae and cyanobacteria are the base of the

*Author for correspondence: surodgher@uol.com.br 
detritus and grazing food webs in aquatic systems and in addition, cyanobacteria are important nitrogen fixers. In this sense, studies on the response of these organisms to metals are of particular relevance. Microalgae constitute an important group of photosynthetic organisms that present high sensitivity for the metals, and for this reason they are frequently used for the assessment of the impacts of these elements on aquatic ecosystems. Besides their sensitivity, microalgae are fast growing organisms and relatively simple to follow and maintain under culture conditions, what makes them ideal organisms for the ecotoxicological investigations.

Cyanobacteria are an ancient, large and diverse group of prokaryotic autotrophs. The widespread nature of cyanobacteria in different environments makes them useful as the indicators of environmental pollution (Whitton 1984). Knowledge of the cyanobacteria's response for metal additions is ecologically important due to its high frequency in the aquatic environments in several countries around the world, including Brazil. Cyanobacterial blooms are very frequent episodes partially as a consequence of favorable climatic conditions, but mainly due to the overenrichment of environment (Sotero-Santos et al. 2008; Figueredo and Giani 2009).

Literature data show that total metal concentration is not a good predictor of bioavailability, toxicity and mobility of metals in the environment (Sunda and Huntsman 1998), whereas the concentration of free ions are closely related to its bioavailability (Campbell et al. 2002; Almas et al. 2006; Worms et al. 2007). Cadmium and chromium have high affinity for the particles (Guéguen et al. 2004), sediment (Murakami et al. 2008) and biological surfaces (Vigneault and Campbell 2005), which may account as significant environmental factors that modify $\mathrm{Cd}$ and $\mathrm{Cr}$ speciation, thus controlling their availability and toxicity to organisms.

Due to the environmental importance of microalgae and cyanobacteria, studies focusing on the response of these organisms to metals are of particular interest. Both the cadmium and chromium are present in the contaminated aquatic ecosystems and pose risk to the aquatic organisms. At present, few information is available in the literature that show the sensitivity of two different algal species (prokaryote and eukaryotic) to cadmium and chromium (Thompson et al. 2002), as well as their capacity for metal accumulation.
The main objective of this study was to evaluate the toxic effects of the cadmium and chromium on green algae Pseudokirchneriella subcapitata and cyanobacteria Microcystis aeruginosa using growth rate inhibition as toxicity endpoint. Metal accumulation by microorganisms was also evaluated.

\section{MATERIALS AND METHODS}

\section{Microorganisms}

Pseudokirchneriella subcapitata was kept in batch cultures in the Laboratory of Ecotoxicology and Ecophysiology of Aquatic Organisms of São Paulo University (São Carlos, Brazil). The inoculum of P. subcapitata was obtained from the Phycology laboratory at Universidade Federal de São Carlos, gently donated by Prof. A. Vieira. A strain of the cyanobacterium Microcystis aeruginosa that did not produce toxins was gently supplied by Prof. Dr. S. Azevedo (Federal University of Rio de Janeiro, RJ, Brazil).

The green algae was cultured in L.C. Oligo medium that did not contain ethylenediaminetetraacetic acid (EDTA) (AFNOR 1980) and the cyanobacterium in ASM-1 culture medium (Gohram et al. 1964), which contained EDTA. Culture media were sterilized by autoclaving at $121{ }^{\circ} \mathrm{C}$ during 15 minutes. Algal cells were grown in $1 \mathrm{~L}$ of media in $2 \mathrm{~L}$ borosilicate Erlenmeyer flasks under a 12h:12h (light:dark cycle) using "cool-white" fluorescent lamps, $\quad 100 \mu \mathrm{mol}$ photons $\mathrm{m}^{-2} \mathrm{~s}^{-2}$ for the Chlorophyceae and $50 \mu \mathrm{mol}$ photons $\mathrm{m}^{-2} \mathrm{~s}^{-2}$ for the Cyanobacteria. Controlled temperature was used throughout $\left(24 \pm 2{ }^{\circ} \mathrm{C}\right)$. Experimental conditions followed the Brazilian protocol (ABNT 2005) for green algae and American standard practice (APHA 1995) for the cyanobacteria.

\section{Toxicity tests}

$P$. subcapitata and $M$. aeruginosa were exposed for $96 \mathrm{~h}$ to a range of chromium and cadmium concentrations. Due to different metal sensitivities (Rodgher 2005), each alga was submitted to a different set of metal concentration range. Filtrates from the algal cultures were used for the determination of total dissolved metal concentrations. The filtrates were obtained by gentle vacuum filtration of $100 \mathrm{~mL}$ of algal culture using acid washed cellulose acetate membrane 
filters (Schleicher and Schull) with $0.45 \mu \mathrm{m}$ pore size. Total dissolved cadmium concentrations used for the toxicity tests performed with $P$. subcapitata were $0.06,0.15,0.29,0.68$ and $1.29 \mu \mathrm{mol} \mathrm{L}^{-1}$, and $1.78,3.24,7.11,14.5$ and $28.1 \mu \mathrm{mol} \mathrm{L}^{-1}$ for the cyanobacteria. Initial total dissolved chromium concentrations used for the toxicity tests with $P$. subcapitata were $1.82,3.57,7.36,14.9$ and 27.4 $\mu \mathrm{mol} \mathrm{L} \mathrm{L}^{-1}$, and those for M. aeruginosa were 1.87, $3.59,7.41,15.2$ and $29.7 \mu \mathrm{mol} \mathrm{L}^{-1}$.

Considering that the free metal ions constitute an important metal fraction related to the bioavailability to microalgae and cyanobacteria, the chemical equilibrium software $\mathrm{MINEQL}^{+} 4.61$ $\left(\mathrm{MINEQL}^{+}\right.$version 4.612009$)$ was used for the calculation of $\mathrm{Cr}^{6+}$ and $\mathrm{Cd}^{2+}$ concentrations. In the present study, this was particularly important because the culture medium differed in their composition and chromium and cadmium have different affinities for organic ligands.

The metals were furnished as $\mathrm{Cd}\left(\mathrm{NO}_{3}\right)_{2} \cdot 4 \mathrm{H}_{2} \mathrm{O}(\mathrm{J}$. $\mathrm{T}$. Baker) and $\mathrm{K}_{2} \mathrm{Cr}_{2} \mathrm{O}_{7}$ (Merck) titrimetric solutions diluted to $8.9 \times 10^{-5} \mathrm{~mol} \mathrm{~L}^{-1} \mathrm{Cd}$ and $1.9 \times 10^{-4} \mathrm{~mol} \mathrm{~L}^{-1} \mathrm{Cr}$. Tests were carried out in 250 $\mathrm{mL}$ borosilicate Erlenmeyer flasks containing 100 $\mathrm{mL}$ of medium to which suitable volumes of metal standards were added to achieve the total final concentrations reported above. The cells of $P$. subcapitata and $M$. aeruginosa in the exponential growth phase were inoculated to test flasks to provide initial cell densities of approximately $10^{4}$ cells $\mathrm{mL}^{-1}$. Controls (without added chromium or cadmium) were considered using the same conditions as the experiments with the metals. The flasks were kept on an orbital shaker at $150 \mathrm{rpm}$. Environmental conditions used for the experiments were the same as described for algal cultures (ABNT 2005; APHA 1995). All the materials used for culture and toxicity experiments were washed with $10 \% \mathrm{HNO}_{3}$ for seven days and rinsed with distilled water prior to use. All the experiments were performed with three replicates per treatment.

The samples $(2.0 \mathrm{~mL})$ were taken every $24 \mathrm{~h}$ from each test flask, fixed with acid Lugol's iodine solution and used for the determination of cell density. The cells were counted using an Improved Newbauer-Bright Line hemocytometer under optical microscope (Carl Zeiss, Standard model 25). Dry weight of the microorganisms were obtained by filtering a known volume of the culture on a pre-weighed glass-fiber filter. Filters with the algal cells were dried at $60{ }^{\circ} \mathrm{C}$ for $24 \mathrm{~h}$ and weighed to determine the cell mass per volume of the culture (APHA 1995). The microorganisms growth rates $\left(\right.$ days $\left.^{-1}\right)$ were calculated as described by Fogg (1975) and the data were used to obtain $96 \mathrm{~h}$ IC 50 for each metal.

\section{Metal analysis}

To determine the total dissolved metals at the beginning of the experiments, the samples were filtered through the membrane filters (cellulose acetate, Schleicher and Schüll) with $0.45 \mu \mathrm{m}$ pore size and then acidified with concentrated nitric acid (J. T. Baker). Total cell metal (absorbed and adsorbed by the microorganisms) was determined at the end of the experiments using the cells retained in the membrane filters. These were dried and submitted to acid digestion $(3.0 \mathrm{~mL}$ of concentrated $\mathrm{HNO}_{3}$ and $1.0 \mathrm{~mL}$ of $\mathrm{H}_{2} \mathrm{O}_{2}$, J. T. Baker). The results are expressed as $\mu$ mol metal $\mathrm{mg}^{-1}$ dry weight of algae (APHA 1995). Three replicates were used per metal determination.

Analytical blank was performed using three clean filters according to Van Loon (1985). All the samples were analyzed by graphite furnace atomic absorption spectrometry (Varian AA 220). The detection limits for $\mathrm{Cd}$ and $\mathrm{Cr}$ were calculated as described by Miller and Miller (1993) and were $4 \times 10^{-10} \mathrm{~mol} \mathrm{~L}^{-1}$ for $\mathrm{Cd}$ and $1.6 \times 10^{-8} \mathrm{~mol} \mathrm{~L}^{-1}$ for $\mathrm{Cr}$.

\section{Data analysis}

The $96 \mathrm{~h}$ IC50 values and their 95\% confidence intervals were determined by the Trimmed Spearman-Karber method (Hamilton et al. 1977). The result for the dry weight was submitted to tests for normality (Shapiro-Wilk's test) and homogeneity (Bartlett's test). The results were then analyzed through ANOVA and Dunnett's test was applied to detect the significant differences among the controls and metal treatments. Tukey's test (post hoc test) was used in multiple comparisons to detect the significant differences among the total dissolved metal and free metal ion concentrations. The above statistical tests were run using the BioEstat 4.0 program (Ayres et al. 2005).

\section{RESULTS}

Metal speciation results are reported in Figure 1. The calculations showed that the presence of EDTA in ASM-1 culture medium significantly 
reduced free $\mathrm{Cd}^{2+}$ ions concentration in the culture (Tukey's test, $P<0.05$ ). The concentrations of total dissolved cadmium used in the experiments with the cyanobacteria ranged from 1.78 to $28.1 \mu \mathrm{mol}$ $\mathrm{L}^{-1}$, with its free ion concentration ranging from 0 to $27 \%$. In relation to chromium, the furnished range of total concentration was 1.87 to $29.7 \mu \mathrm{mol}$ $\mathrm{L}^{-1}$, which corresponded to a free $\mathrm{Cr}^{6+}$ concentration of $100 \%$. Total dissolved metal concentration in L.C. Oligo culture medium, which did not contain EDTA, corresponded to a free $\mathrm{Cd}^{2+}$ ion concentration of $96 \%$ and $100 \%$ for $\mathrm{Cr}$. Considering these different behaviors of metal ions in the culture media and its importance as bioavailable fraction, toxicity evaluation (IC50) was based on the free metal ions concentration and not on their total dissolved concentrations.

The IC50 values for the metals for the microorganisms are shown in Table 1 . Based on IC50 values, it was concluded that cadmium was more toxic than chromium to both the algae $P$. subcapitata and cyanobacteria $M$. aeruginosa. For the green algae, values of IC50 were $0.60 \mu \mathrm{mol} \mathrm{L}^{-1}$ free $\mathrm{Cd}^{2+}$ and $20 \mu \mathrm{mol} \mathrm{L} \mathrm{L}^{-1}$ free $\mathrm{Cr}^{6+}$. The values obtained for the cyanobacteria revealed an IC 50 of $0.01 \mu \mathrm{mol} \mathrm{L}^{-1}$ free $\mathrm{Cd}^{2+}$ and $11.07 \mu \mathrm{mol} \mathrm{L}^{-1}$ free $\mathrm{Cr}^{6+}$.
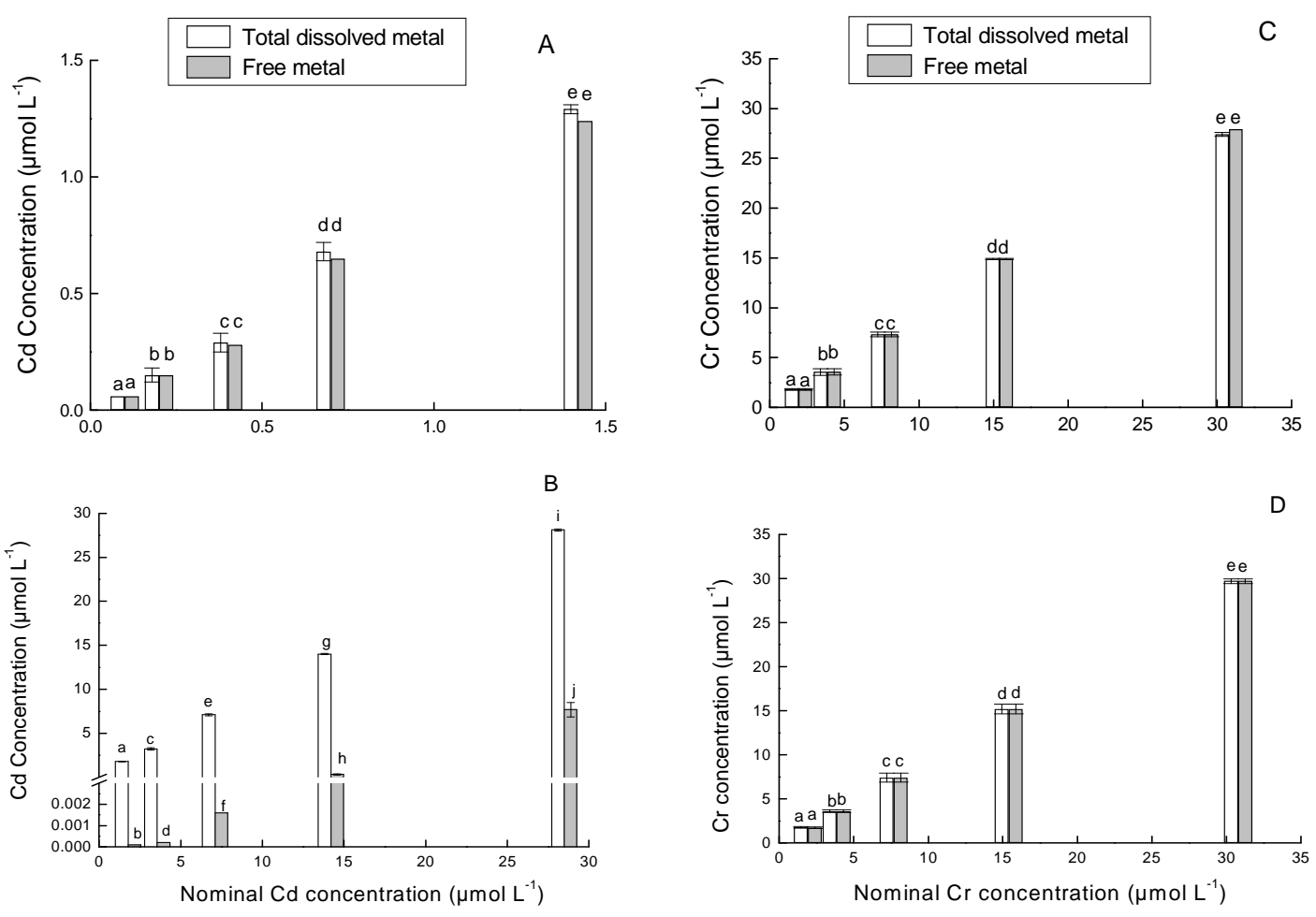

Figure 1 - Initial total dissolved and free metal concentrations for the experimental treatments with $P$. subcapitata (A and C) and M. aeruginosa (B and D). Values are mean \pm SD of 3 replicates. Means with different letters are significantly different (Tukey's test, $P<0.05)$. Error bars denote standard deviation.

Table 1 - Inhibition concentration values (IC50) of free metals for microorganisms. Concentration values are reported in $\mu \mathrm{mol} \mathrm{L}^{-1}$. Values given in parenthesis are $95 \%$ confidence limits.

\begin{tabular}{|c|c|c|c|}
\hline \multicolumn{2}{|c|}{$\mathbf{C d}^{2+}$} & \multicolumn{2}{|c|}{$\mathrm{Cr}^{6+}$} \\
\hline P. subcapitata & M. aeruginosa & P. subcapitata & M. aeruginosa \\
\hline $0.60(0.50-0.72)$ & $0.01(0.006-0.02)$ & $20(18-23)$ & $11.07(9.60-12.76)$ \\
\hline
\end{tabular}


The results of IC50 were supported by the reduction of dry weight for both the microorganisms. A significant decrease of dry weight for the green algae was observed at 0.15 $\mu$ mol L ${ }^{-1}$ free $\mathrm{Cd}^{2+}$ (Dunnett's test, $P<0.05$ ). At $14.9 \mu \mathrm{mol} \mathrm{L}{ }^{-1}$ free $\mathrm{Cr}^{6+}$, the dry weight for $P$. subcapitata were lower than that observed in the controls (Dunnett's test, $P<0.05$ ). A reduction of dry weight for $M$. aeruginosa was observed at 0.11 $\mu \mathrm{mol} \mathrm{L} \mathrm{L}^{-1}$ free $\mathrm{Cd}^{2+}$ and $7.41 \mu \mathrm{mol} \mathrm{L}{ }^{-1}$ free $\mathrm{Cr}^{6+}$ (Dunnett's test, $P<0.05$ ) (Table 2).

Total cellular metal concentrations are shown in Figure 2. The total cellular metal increased with increasing of the free metal ions in the solution for
P. subcapitata and $M$. aeruginosa, which continued to accumulate the metal above the 20.0 $\mu$ mol $\mathrm{L}^{-1}$ free $\mathrm{Cr}^{6+}$. $\mathrm{Cd}$ accumulated by $M$. aeruginosa did not increase above $0.11 \mu \mathrm{mol} \mathrm{L}^{-1}$ $\mathrm{Cd}^{2+}$, while green algae accumulated above 1.0 $\mu$ mol L ${ }^{-1}$ free $\mathrm{Cd}^{2+}$. The increase of accumulated Cd by M. aeruginosa in relation to free $\mathrm{Cd}^{2+}$ was smaller than that verified for the green algae. $P$. subcapitata accumulated higher metal concentrations $\left(0.001-0.05 \mu \mathrm{mol} \mathrm{Cd} \mathrm{\textrm {mg } ^ { - 1 }}\right.$ dry wt and $0.001-0.04 \mu \mathrm{mol} \mathrm{Cr} \mathrm{mg}^{-1}$ dry wt) than the cyanobacteria $\left(0.001-0.01 \mu \mathrm{mol} \mathrm{Cd} \mathrm{mg}^{-1}\right.$ dry wt and $0.001-0.02 \mu \mathrm{mol} \mathrm{Cr} \mathrm{mg}^{-1}$ dry wt).

Table 2 - Dry weight $\left(\mathrm{mg} \mathrm{L}^{-1}\right)$ for microorganisms after exposure to metals. Values are mean \pm SD of 3 replicates. Free metals concentrations are reported in $\mu \mathrm{mol} \mathrm{L}{ }^{-1}$. *statistically different from Control (Dunnett's test, $P<0.05$ ).

\begin{tabular}{|c|c|c|c|c|c|c|c|}
\hline \multicolumn{4}{|c|}{ P. subcapitata } & \multicolumn{4}{|c|}{ M.aeruginosa } \\
\hline $\mathrm{Cd}^{2+}$ & Dry weight & $\mathrm{Cr}^{6+}$ & Dry weight & $\mathbf{C d}^{2+}$ & Dry weight & $\mathrm{Cr}^{6+}$ & Dry weight \\
\hline Control & $137.1 \pm 23.4$ & Control & $110.7 \pm 18.5$ & Control & $22.2 \pm 4.4$ & Control & $20.4 \pm 4.7$ \\
\hline 0.06 & $92.2 \pm 27.3$ & 1.82 & $121.5 \pm 29.8$ & 0.0001 & $21.9 \pm 3.0$ & 1.87 & $21.8 \pm 6.3$ \\
\hline 0.15 & $89.9 \pm 31.0^{*}$ & 3.57 & $111.9 \pm 39.1$ & 0.0002 & $21.8 \pm 6.2$ & 3.59 & $19.7 \pm 5.0$ \\
\hline 0.28 & $64.5 \pm 16.9^{*}$ & 7.36 & $111.2 \pm 2.6$ & 0.002 & $17.9 \pm 4.2$ & 7.41 & $11.3 \pm 1.6^{*}$ \\
\hline 0.65 & $24.9 \pm 6.3^{*}$ & 14.9 & $49.6 \pm 19.8^{*}$ & 0.11 & $6.8 \pm 2.0^{*}$ & 15.20 & $7.4 \pm 1.2^{*}$ \\
\hline 1.24 & $9.7 \pm 2.7^{*}$ & 27.4 & $9.8 \pm 2.3^{*}$ & 7.68 & $3.4 \pm 1.8^{*}$ & 29.70 & $7.1 \pm 1.6^{*}$ \\
\hline
\end{tabular}

\section{DISCUSSION}

In unpolluted freshwater environments, dissolved metal concentrations can reach values close to $4 \times 10^{-8} \mathrm{~mol} \mathrm{~L}^{-1} \mathrm{Cd}$ and $4 \times 10^{-7} \mathrm{~mol} \mathrm{~L}^{-1} \mathrm{Cr}$ (Ochieng et al. 2008). It has been detected that in the contaminated areas, water may contain dissolved metal concentrations as high as $9 \times 10^{-7} \mathrm{~mol} \mathrm{~L}^{-1} \mathrm{Cd}$ (Sainz et al. 2004) and $2 \times 10^{-6} \mathrm{~mol} \mathrm{~L}^{-1} \mathrm{Cr}$ (Bobrowski et al. 2004). In the present study, the concentration of $\mathrm{Cd}$ and $\mathrm{Cr}$ to which the microorganisms were exposed were similar to the values observed in impacted aquatic systems. However, the concentration of organic and inorganic ligands in the natural waters normally exceeds the trace metal concentrations (Gopalakrishnan et al. 2008), thereby forming the complexes and rending the metal ions less bioavailable to the aquatic organisms. Because free metal concentrations are closely related to the bioavailable fraction of the total dissolved metal, the metals toxicity was related it directly to the free ion species in the culture media.
The IC50 for the cadmium obtained in the present study for $P$. subcapitata $\left(0.60 \mu \mathrm{mol} \mathrm{L}{ }^{-1}\right.$ free $\left.\mathrm{Cd}^{2+}\right)$ was lower than the value obtained by Castañé et al. (2003) for the same metal and same algal species. Using the culture media with EDTA in their algal bioassays, the authors observed that IC50 value for the $\mathrm{Cd}$ based on MINEQL ${ }^{+}$ calculated free $\mathrm{Cd}^{2+}$ ion was $1.06 \mu \mathrm{mol} \mathrm{L} \mathrm{L}^{-1}$, lower than that based on the total metal concentration $\left(2.25 \mu \mathrm{mol} \mathrm{L}^{-1}\right.$ total $\left.\mathrm{Cd}\right)$. The present results were in agreement to those of Errecalde et al. (1998), who found $50 \%$ reduction in the growth rate of $P$. subcapitata at $0.65 \mu \mathrm{mol} \mathrm{L}^{-1}$ free $\mathrm{Cd}^{2+}$ after $72 \mathrm{~h}$ of metal exposure. However, the IC50 value of 20 $\mu$ mol $\mathrm{L}^{-1}$ free $\mathrm{Cr}^{6+}$ obtained for $P$. subcapitata in the present study was lower than that found by Brady et al. (1994). Using the test medium with EDTA the authors reported that the growth of $P$. subcapitata was affected only at concentrations of total Cr higher than $2 \times 10^{-4} \mathrm{~mol} \mathrm{~L}^{-1}$.

For $M$. aeruginosa, the results showed an IC50 value of $0.01 \mu \mathrm{mol} \mathrm{L}^{-1}$ free $\mathrm{Cd}^{2+}$. This value was approximately 80-fold lower than the IC50 obtained if total dissolved $\mathrm{Cd}$ was considered. This 
emphasized the importance of free ions estimation in the toxicity tests with the microorganisms. Neelam and Ray (2003) found 50\% inhibition of photosynthetic pigments in Microcystis sp. at 0.27 $\mu \mathrm{mol} \mathrm{L}{ }^{-1}$ total $\mathrm{Cd}$ in the cultures with less EDTA
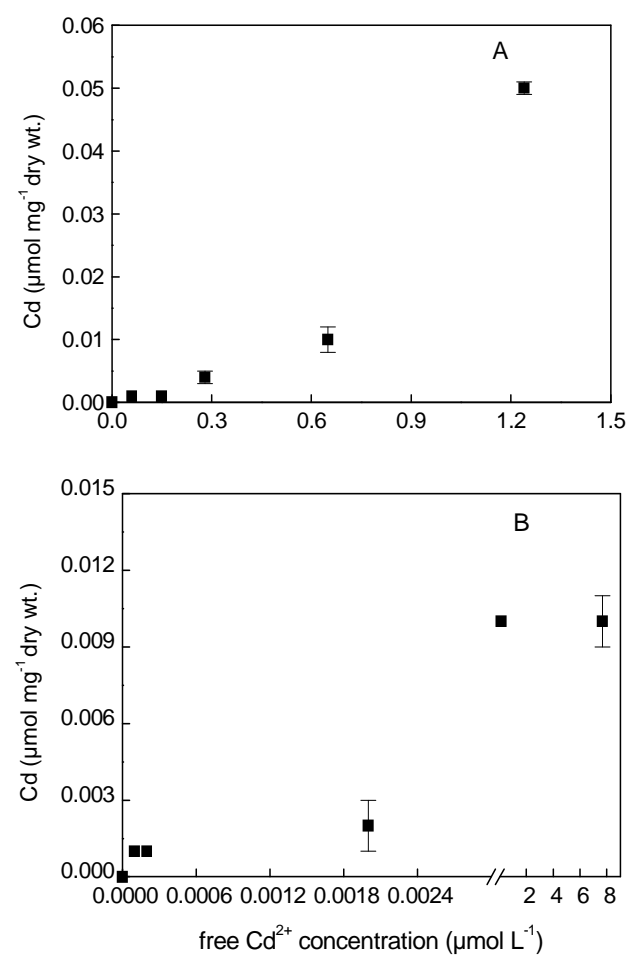

than was used in the present work. Zhou et al. (2006) found inhibition of $M$. aeruginosa growth on the basis of chlorophyll a content at $4 \mu \mathrm{mol} \mathrm{L}{ }^{-1}$ total $\mathrm{Cd}$ in the medium with chelator addition (1.78 $\mu \mathrm{mol} \mathrm{L}^{-1}$ free $\mathrm{Cd}^{2+}$, MINEQL ${ }^{+}$calculation).
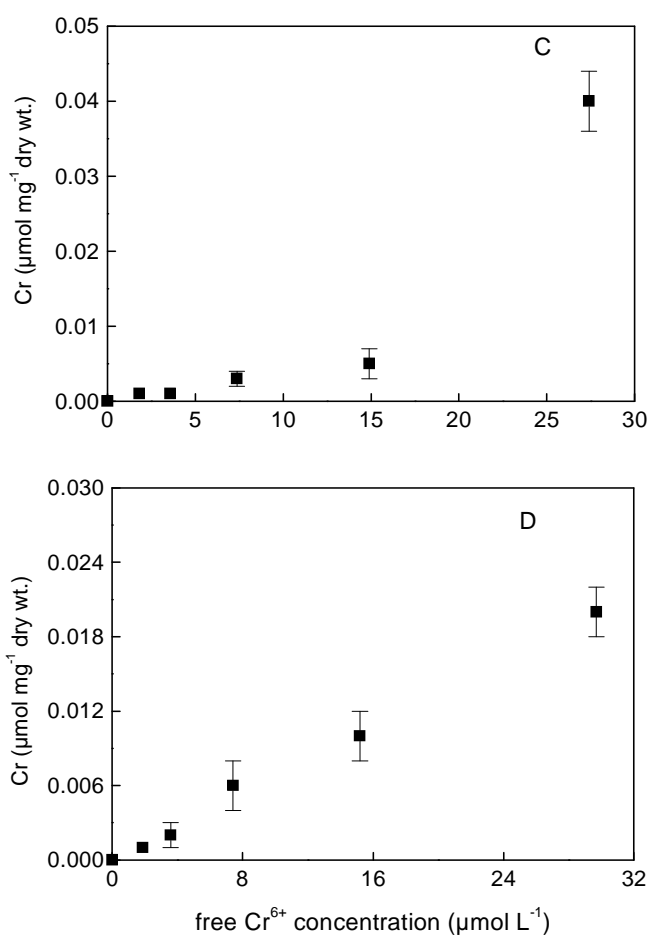

Figure 2 - Metals accumulated in the microorganisms after $96 \mathrm{~h}$ of exposure. A and C: $\mathrm{Cd}$ and $\mathrm{Cr}$ accumulated in $P$. subcapitata. B and D: $\mathrm{Cd}$ and $\mathrm{Cr}$ accumulated in M. aeruginosa. Error bars denote standard deviation.

Only few studies have been reported in literature about $\mathrm{Cr}^{6+}$ toxicity to cyanobacteria. Thompson et al. (2002) found growth inhibition of Synechococcus $\mathrm{sp}$. and Nostoc sp. at $1.0 \times 10^{-3} \mathrm{~mol}$ $\mathrm{L}^{-1}$ and $750 \mu \mathrm{mol} \mathrm{L}{ }^{-1}$ total $\mathrm{Cr}$, respectively. Thus, the present study represented an attempt to fill a gap in the information about the toxic effect of chromium on cyanobacteria.

In the present investigation, EDTA was kept in the experiments with $M$. aeruginosa because preliminary studies demonstrated that ASM-1 medium without this metal chelator was not suitable for the growth of the tested cyanobacteria (Rodgher 2005). It is known that EDTA is necessary to maintain $\mathrm{Fe}$ in the solution, an important oligoelement for microalgae (Lewis 1995). Chemical speciation modeling of the present results showed that the presence of such ligand reduced free $\mathrm{Cd}^{2+}$ ions in the medium, but not $\mathrm{Cr}^{6+}$. Guéguen et al. (2003) also demonstrated that the behavior of metals was influenced by the experimental conditions used for algal bioassays and suggested working with EDTA free medium to avoid complexation with the metals, especially for cadmium. Moreover, as shown by the results, the chelating effect of EDTA varied according to the metal, so special care should be taken when interpreting the results.

The population growth rate is one of the important endpoints used in the toxicity tests since toxic effects are reflected in cell growth. The growth of $P$. subcapitata and $M$. aeruginosa decreased with increasing the cadmium and chromium concentrations. Reduction in the growth rate caused by exposure to metals can be attributed to the loss of cellular constituents and poor nutrient uptake, which may be a consequence of altered membrane permeability and inhibition of the photosynthesis (Pistocchi et al. 2000). 
The accumulation of metals by $P$. subcapitata and $M$. aeruginosa was dependent on external free metal ion concentrations, with higher metal accumulation by the green algae when compared to the cyanobacteria. Similarly, a positive correlation between the accumulated $\mathrm{Cd}$ by green algae and the concentration of free $\mathrm{Cd}$ in the solution has been described by Wang and Dei (2006). The authors showed the accumulation of $\mathrm{Cd}$ by Chlamydomonas reinhardtii at a medium concentration over $1.0 \mu \mathrm{mol} \mathrm{L}^{-1}$ free $\mathrm{Cd}^{2+}$. Also, Brady et al. (1994) reported that Pseudokirchneriella sp. was the most efficient $\mathrm{Cr}$ accumulator at $2 \times 10^{-4} \mathrm{~mol} \mathrm{~L}^{-1}$ in comparison to Chlorella sp. and Scenedesmus sp., but all the three species have accumulated the metal.

In relation to the cyanobacteria, the present study disagreed with those of Klimmek et al. (2001) and Zeng et al. (2009). Zeng et al. (2009) observed the accumulation of $\mathrm{Cd}$ by $M$. aeruginosa at concentrations higher than $0.20 \mu \mathrm{mol} \mathrm{L} \mathrm{L}^{-1}$ free $\mathrm{Cd}^{2+}$, while Klimmek et al. (2001) showed that $M$. aeruginosa accumulated $\mathrm{Cd}$ at a medium concentration of $9 \times 10^{-4} \mathrm{~mol} \mathrm{~L}^{-1}$ total $\mathrm{Cd}$. The present results showed that $\mathrm{Cd}$ accumulation by $M$. aeruginosa reached a saturation level at $0.11 \mu \mathrm{mol}$ $\mathrm{L}^{-1}$ free $\mathrm{Cd}^{2+}$, above which no increase was observed. This difference could be explained by the longer exposure time employed in the present study (96 h) as compared to lower exposure time ( $24 \mathrm{~h}$ ) by Klimmek et al. (2001) and (48 h) by Zeng et al. (2009) studies.

Cadmium is a major metal pollutant due to its toxicity. In the present study, cadmium was more toxic than chromium to both the microorganisms. $M$. aeruginosa was a more sensitive organism for cadmium than $P$. subcapitata. The results were consistent with those obtained by Guanzon et al. (1994) who have investigated the effects of metals $(\mathrm{Cu}, \mathrm{Pb}$ and $\mathrm{Cd})$ on the growth rates of three freshwater microalgae and concluded that $M$. aeruginosa exhibited higher sensitivity than other species to cadmium.

In relation to chromium, the cyanobacteria also showed higher sensibility to the metal in comparison to the green algae. Similar to the present study, Chen et al. (2003) found higher chromium tolerance by the green algae $P$. subcapitata $\left(\mathrm{EC} 50=2.40 \times 10^{-4} \mathrm{M}\right.$ total $\left.\mathrm{Cr}\right)$ in relation to the cyanophyta Synechococcus sp. $\left(\mathrm{EC} 50=1.25 \times 10^{-4} \mathrm{M}\right.$ total $\left.\mathrm{Cr}^{6+}\right)$.
The results of the present study demonstrated the importance of using free metal ion concentrations to evaluate the metal toxicity to phytoplankton cells. This is most important when metal ligands are added to the culture media, since it is necessary to optimize the growth of the microorganisms.

Finally, it is important to consider two points: metal accumulation by the microorganisms and difference in sensitivity. The accumulation of the metals by $P$. subcapitata and $M$. aeruginosa could be considered a potential contamination source in the aquatic systems. The metal accumulated by the cell could be interpreted as the total particulate metal (metal species as quantified in this study). For example, the metal that is transported with the cell to other trophic levels, as demonstrated in literature (Fisher and Hook 2002; Wilding and Maltby 2006; Geffard et al. 2008). In addition, $M$. aeruginosa showed higher sensibility to the metals in comparison to the green algae, showing that the cyanobacterium was more suitable for monitoring the contaminated aquatic bodies with $\mathrm{Cd}$ and $\mathrm{Cr}$. However, other factors might influence the metal toxicity to the microorganisms in the environment. Future studies should be performed in order to better assess the sensitivity of the green algae and cyanobacteria to the metals.

\section{ACKNOWLEDGMENTS}

We thank Dr. Ana T. Lombardi for comments on this work. This study was supported by the National Research Council $(\mathrm{CNPq}$ proc. no. 140156/2002-0) and State of São Paulo Research Aid Foundation (FAPESP proc. no. 10417/2002).

\section{REFERENCES}

Almas AR, Lombnaes P, Sogn TA, Mulder J. Speciation of $\mathrm{Cd}$ and $\mathrm{Zn}$ in contaminated soils assessed by DGT-DIFS, and WHAM/ Model VI in relation to uptake by spinach and ryegrass. Chemosphere. 2006; 62(10): 1647-1655.

American Public Health Association; American Water Work Association; Water Control Federation APHA/AWWA/WCPF. Standard methods for he examination of water and wastewater.19 ed. New York; 1995. 
Associação Brasileira de Normas Técnicas ABNT. Ecotoxicologia aquática - toxicidade crônica Método de ensaio com algas (Chlorophyceae) NBR12468. Rio de Janeiro; 2005.

Association Française de Normalisation AFNOR. Essais deseaux. Norme experimentale T90-304. Determination de I'inhibition de croissance Scenesdesmus subspicatus par une substance. Paris; 1980.

Ayres M, Ayres MJr, Ayres DL, Santos AS. BioEstat 4.0: Aplicações Estatística nas Áreas das Ciências Bio-Médicas. Maringá: Gráfica Ltda; 2005.

Bagchi D, Stohs SJ, Downs M, Bagchi M, Preuss HG. Cytotoxicity and oxidative mechanisms of different forms of chromium. Toxicology. 2002; 180(1): 5-22.

Bobrowski A, Bás B, Dominik J, Niewiara E, Szalinska E, Vignati D, Jerzy Z. Chromium speciation study in polluted waters using catalytic adsorptive stripping voltammetry and tangential flow filtration. Talanta. 2004; 63(4-8): 1003-1012.

Brady D, Letebele B, Duncan JR, Rose PD, Bioaccumulation of metals by Scenedesmus, Selenastrum and Chlorella algae. Water SA. 1994; 20(3): 213-218.

Campbell PGC, Errécalde O, Fortm C, Hiriart-Baer V, Vigneault B. Metal bioavailability to phytoplanktonapplicability of the biotic ligand model. Comp Biochem Physiol C. 2002; 133(1-2): 189-206.

Castañé PM, Topalián ML, Cordero RR, Salibián A. Influencia de la especiación de los metales pesados en medio acuático como determinante de su toxicidad. Rev Toxicol 2003; 20:13-18.

Chen H, Pan G, Yan H, Quin Y. Toxic effects of hexavalent chromium on the growth of blue-green microalgae. Huan Jing Ke Xue. 2003; 24: 13-8.

Davis TA, Volesky B, Vieira RHSF. Sargassum seaweed as biosorbent for heavy metals. Water Res. 2000; 34(17): 4270-4278.

De Schamphelaere KAC, Stauber JL, Wilde KL, Markich SJ, Brown PL, Franklin NM, et al. Toward a biotic ligand model for freshwater green algae: surface-bound and internal copper are better predictors of a toxicity than a free $\mathrm{Cu}^{+2}$-ion activity when $\mathrm{pH}$ is varied. Environ Sci Technol. 2005; 39(7): 2067-2072.

Errecalde O, Seidl M, Campbell PGC. Influence of a low molecular weight metabolite (citrate) on the toxicity of cadmium and zinc to the unicellular green alga Selenastrum capricornutum: an exception to the free-ion model. Water Res. 1998; 32(2): 419-429.

Figueredo CC, Giani A. Phytoplankton community in the tropical lake of Lagoa Santa (Brazil): Conditions favoring a persistent bloom of Cylindrospermopsis raciborskii. Limnologica. 2009; 39(4): 264-272.
Fogg GE. Algal cultures and phytoplankton ecology. 2nd ed. Madison: University of Wisconsin Press; 1975.

Geffard O, Geffard A, Chaumot A, Vollat B, Alvarez C, Tusseau-Vuillemin MH et al. Effects of chronic dietary and waterborne cadmium exposure on the contamination level and reproduction of Daphnia magna. Environ Toxicol Chem. 2008; 27(5): 11281134.

Gopalakrishnan S, Thilagam H, Vivek Raja P. Comparison of heavy metal toxicity in life stages (spermiotoxicity, egg toxicity, embryotoxicity and larval toxicity) of Hydroides elegans. Chemosphere. 2008; 71(3): 515-528.

Gorham PR, McLachlan J, Hammer UT, Kim WK. Isolation and culture of toxic strains of Anabaena flosaquae (Lingb). Verh Internat Verein Limnol. 1964; 15: 796-780.

Guanzon NGJr, Nakahara II, Yoshida Y. Inhibitory effects of heavy metals on growth and photosynthesis of three freshwater microalgae. Fisheries Science. 1994; 60(4): 379-384.

Guéguen C, Gilbin R, Pardos M, Dominio J. Water toxicity and metal contamination assessment of a polluted river: the Upper Vistula River (Poland). Appl Geochem. 2004; 19(1): 153-162.

Guéguen C, Koukal B, Dominik J, Pardos M. Competition between alga (Pseudokirchneriella subcapitata), humic substances and EDTA for Cd and $\mathrm{Zn}$ control in the algal assays procedure (AAP) medium. Chemosphere. 2003; 53(8): 927-934.

Hamilton MA, Russo RC, Thurston RV. Trimmed Spearman-Karber method for estimating median lethal concentrations in toxicity bioassays. Environ Sci Technol. 1977; 11(7): 714-719.

Hook SE, Fisher NS. Relating the reproductive toxicity of five ingested metals in calanoid copepods with sulfur affinity. Mar Environ Res. 2002; 53(2): 161174.

Klimmek S, Stan HJ, Wilke A, Bunke G, Buchholz R. Comparative analysis of the biosorption of cadmium, lead, nickel and zinc by algae. Environ Sci Technol. 2001; 35(21): 4283-4288.

Lewis MA. Algae and vascular plant test. In: Rand GM, editor. Fundamentals of aquatic toxicology: effects, environmental fate, and risk assessment. Washington: Taylor \& Francis; 1995. p. 135-169.

Lombardi AT, Vieira AAH, Sartori LA. Mucilaginous capsule adsorption and intracellular uptake of copper by Kirchneriella aperta (Chlorococcales). J Phycol. 2002; 38(2): 332-337.

Miller JC, Miller JN. Statistics for Analytical Chemistry. 3rd ed. New York: Ellis Horwood PTR Prentice Hall; 1993. 
$\mathrm{MINEQL}^{+}$version 4.61 Chemical equilibrium modeling system for windows environmental research software. Hollowell; 2009

Murakami M, Nakajima F, Furumai H. The sorption of heavy metal species by sediments in soakaways receiving urban road runoff. Chemosphere. 2008; 70(11): 2099-2109.

Neelam A, Rai LC. Differential responses of three cyanobacteria to UV-B and Cd. J. Microbiol Biotechnol. 2003; 13(4): 544-551.

Ochieng EZ, Lalah EJO, Wandiga ESO. Water quality and trace metal distribution in a Pristine Lake in the Lake Basin in Kenya. Bull Environ Contam Toxicol. 2008; 80(4): 362-368.

Pistocchi R, Mormile AM, Guerrini F, Isani G, Boni L. Increased production of extra-and intracellular metalligands in phytoplankton exposed to copper and cadmium. J Appl Phycol. 2000; 12(3-5): 469-477.

Rodgher S. Avaliação dos efeitos ecotoxicológicos dos metais cádmio e cromo sobre organismos planctônicos [PhD Thesis]. São Carlos, Brazil: Universidade de São Paulo; 2005.

Sainz A, Grande AJA, De la Torre ML. Characterisation of heavy metal discharge into the Ria of Huelva. Environ Int. 2004; 30(4): 557- 566.

Sotero-Santos RB, Carvalho EG, Dellamano-Oliveira MJ, Rocha O. Occurrence and toxicity of an Anabaena bloom in a tropical reservoir (Southeast Brazil). Harmful Algae. 2008; 7(5): 590-598.

Sunda WG, Huntsman SA. Processes regulating cellular metal accumulation and physiological effects: Phytoplankton as model systems. Sci Total Environ. 1998; 219 (2-3): 165-181.

Thompson SL, Manning FCR, McColl SM. Comparison of the toxicity of chromium III and chromium VI to cyanobacteria. Bull Environ Contam Toxicol. 2002; 69(2): 286-293.
Töpperwien S, Xue H, Behra R, Sigg L. Cadmium accumulation in Scenedesmus vacuolatus under freshwater conditions. Environ Sci Technol. 2007; 41(15), 5383-5388.

Van Loon JC. Select methods of trace metal analysis. United States: John Wiley and Sons; 1985.

Vigneault B, Campbell PGC. Uptake of cadmium by freshwater green algae: effects of $\mathrm{pH}$ and aquatic humic substances. J Phycol. 2005; 41(1): 55-61.

Zeng J, Yang L, Wang W-X. Cadmium and zinc uptake and toxicity in two strains of Microcystis aeruginosa predicted by metal free ion activity and intracellular concentration. Aquat Toxicol. 2009; 91(3): 212-220.

Zhou W, Juneau P, Qiu B. Growth and photosynthetic responses of the bloom-forming cyanobacterium Microcystis aeruginosa to elevated levels of cadmium. Chemosphere. 2006; 65(10): 1738-1746.

Wang W-X, Dei RCH. Metal stoichiometry in predicting $\mathrm{Cd}$ and $\mathrm{Cu}$ toxicity to a freshwater green algae Chlamydomonas reinhardtii. Environ Pollution. 2006; 142(2): 303-312.

Whitton BA. Algae as monitors of heavy metals in freshwaters. In: Shubert LE, editor. Algae as Ecological Indicators. London: Academia Press; 1984. p. 257-280.

Wilding J, Maltby L. The relative toxicological importance of aqueous and dietary metal exposure to a freshwater crustacean: implications for risk assessment. Environ Toxicol Chem. 2006; 25 (7): 1795-1801.

Worms IAM, Parthasarathy N, Wilkinson KJ. Ni Uptake by a Green Alga. Validation of equilibrium models for complexation effects. Environ Sci Technol. 2007; 41(12): 4258-4263.
Received: September 09, 2010; Revised: January 27, 2011; Accepted: September 11, 2011. 